\title{
Population Biology of Rhodnius domesticus Neiva \& Pinto, 1923 (Hemiptera: Reduviidae) under Laboratory Conditions
}

\author{
Alessandra A Guarneri, Carlos J Carvalho Pinto, Chris J Schofield/*, \\ Mário Steindel $/^{+}$
}

\begin{abstract}
Departamento de Microbiologia e Parasitologia, Universidade Federal de Santa Catarina, Caixa Postal 476, 88040-900 Florianópolis, SC, Brasil *London School of Hygiene and Tropical Medicine, WC1 E7HT, London, U.K.
\end{abstract}

The entire life cycle of Rhodnius domesticus, fed weekly on mice, was studied under controlled conditions. Aspects related to hatching, life time, mortality, feeding behaviour and fecundity for each stage of the insect life-cycle were evaluated. The hatching rate observed in 100 eggs was $57 \%$ and the mean time of hatching was 15.6 days. Forty-six nymphs (80.7\%) completed the cycle and the mean time from NI to adult was 93.8 days. The average span in days for each stage was 12.4 for NI, 9.8 for NII, 14.2 for NIII, 16.8 for NIV and 25.0 for NV. The number of bloodmeals in each nymphal stage varied from 1 to 3. The mortality rate was $12.3 \%$ for NI, 3.5\% for NII and $1.7 \%$ for NIII and NV nymphs. The mean number of eggs laid per female in a 9-month period was 333.1. Average adult survival rates were $287.6+133$ and $328+73$ days for males and females respectively.

Key words: Rhodnius domesticus - population biology - life cycle - triatomine

The genus Rhodnius currently includes 13 species recognized on morphological characteristics (Lent \& Wygodzinsky 1979, Lent et al. 1993). Of these, several are important as domestic vectors of Trypanosoma cruzi, the causative agent of Chagas disease, although the majority are of silvatic habit associated particularly with palm tree crowns (Schofield 1994). Some Rhodnius species are also vectors of $T$. rangeli, a parasite generally considered as being non-pathogenic to man (D'Alessandro-Bacigalupo \& Saravia 1992).

In spite of its name, Rhodnius domesticus Neiva $\&$ Pinto is known only from silvatic habitats in the Atlantic forest region of the states of Bahia, Espírito Santo, Rio de Janeiro, São Paulo, Paraná and Santa Catarina. Little is known about the biological aspects of this species. However, it is found mainly in rodent or marsupial nests in epiphytic bromeliads, and occasionally in hollow trees. On the Island of Santa Catarina, $R$. domesticus populations from small mammal nests show infection rates with T. cruzi of over 50\% (Galvão et al. 1961, Leal et

This study was partly supported by the ECLAT network, through EC grant number TS3*CT92-0092 and also by CNPq and CAPES.

${ }^{+}$Corresponding author. Fax: +55-48 331.9512. E-mail: ccb1mst@ccb.ufsc.br

Received 20 September 1997

Accepted 18 December 1997 al. 1961, Schlemper Jr et al. 1985). Experimental studies indicate that $R$. domesticus is also an important vector of $T$. rangeli amongst its mammalian hosts (Steindel et al. 1991). As part of a larger study on the comparative biosystematics of the genus Rhodnius, we present here the results of studies of the population biology of $R$. domesticus under experimental conditions.

\section{MATERIALS AND METHODS}

The insects used in this study were derived from a laboratory colony established in 1985 from bugs captured in the locality of Ribeirão da Ilha, Florianópolis, Santa Catarina. The colony is maintained at the Department of Microbiology and Parasitology of the Federal University of Santa Catarina where the bugs are kept at $25 \pm 4^{\circ} \mathrm{C}, 70 \pm 5 \%$ relative humidity (rh), and are fed weekly on immobilized white mice.

Eggs from the colony were grouped by date of oviposition to initiate a cohort of 100 eggs. After eclosion, the first-instar nymphs were separated individually into plastic tubes $(3.5 \mathrm{~cm}$ diameter $\mathrm{x} 4$ $\mathrm{cm}$ height) lined with white filter paper and closed with cotton netting. Three days after eclosion, the nymphs were individually offered a feed on immobilized white mice during a $5 \mathrm{hr}$ period each day until the first blood meal, after which they were offered a weekly feed. Bugs were maintained in a dark incubator at $28 \pm 1^{\circ} \mathrm{C}, 75 \pm 5 \% \mathrm{rh}$, and were checked daily for ecdysis or death. 
From the insects that completed development to the adult stage, 15 pairs were set up, each in individual tubes ( $8 \mathrm{~cm}$ diameter $\mathrm{x} 8 \mathrm{~cm}$ height) and maintained as before to determine adult survivorship and oviposition pattern.

\section{RESULTS}

The egg eclosion rate was $57 \%$ with a mean incubation period of 15.6 days (range 14-17 days). Forty-six nymphs completed the development to the adult stage ( 25 males and 21 females) (Table I), taking an average of 1.2 blood meals per nymphal stage (range 1-3) (Table II). The mean egg-to-adult development time was 93.8 days (range 77-116 days) (Table I). Adult survival ranged from 37 to 502 days for males (mean $287.6 \pm 133$ ) and from 138 to 444 days for females (mean 328 \pm 73 ). The mean number of eggs laid per female was 335 (range 173-469) (Fig.).

A partial life table analysis, following Southwood (1978), indicates a net reproductive rate $(R o)$ of 70.4 times per generation under these conditions, with an instantaneous daily reproductive rate $(r)$ of 0.053 (Table III).

\section{TABLE I}

Egg to adult development cycle of Rhodnius domesticus fed weekly on mice

\begin{tabular}{lrrcc}
\hline Stage & Number & \multicolumn{3}{c}{ Duration in days } \\
\cline { 2 - 5 } & & Min. & Max. & Mean \pm SD \\
\hline Egg - NI & 57 & 14 & 17 & $15,63 \pm 0,99$ \\
NI - NII & 50 & 9 & 22 & $12,48 \pm 3,42$ \\
NII - NIII & 48 & 8 & 14 & $9,89 \pm 1,37$ \\
NIII - NIV & 47 & 10 & 22 & $14,28 \pm 1,97$ \\
NIV - NV & 47 & 14 & 27 & $16,89 \pm 2,87$ \\
NV - AD & 46 & 18 & 37 & $25,04 \pm 4,99$ \\
\hline Total & 46 & 77 & 116 & $93,85 \pm 7,34$
\end{tabular}

TABLE II

Number of blood meals and stage mortality for Rhodnius domesticus

\begin{tabular}{lccccr}
\hline \multirow{2}{*}{$\begin{array}{c}\text { Stage Number of } \\
\text { nymphs }\end{array}$} & \multicolumn{3}{c}{ Number of bloodmeals } & $\begin{array}{c}\% \\
\text { mortality }\end{array}$ \\
\cline { 3 - 5 } & & Min. & Max. & Mean \pm SD & \\
\hline I & 57 & 1 & 3 & $1,39 \pm 0,5$ & 12.3 \\
II & 50 & 1 & 2 & $1,19 \pm 0,4$ & 3.5 \\
III & 48 & 1 & 2 & $1,08 \pm 0,2$ & 1.7 \\
IV & 47 & 1 & 2 & $1,10 \pm 0,3$ & 0.0 \\
V & 47 & 1 & 3 & $1,28 \pm 0,5$ & 1.7 \\
\hline Total & 46 & - & - & - & 19.2 \\
\hline
\end{tabular}

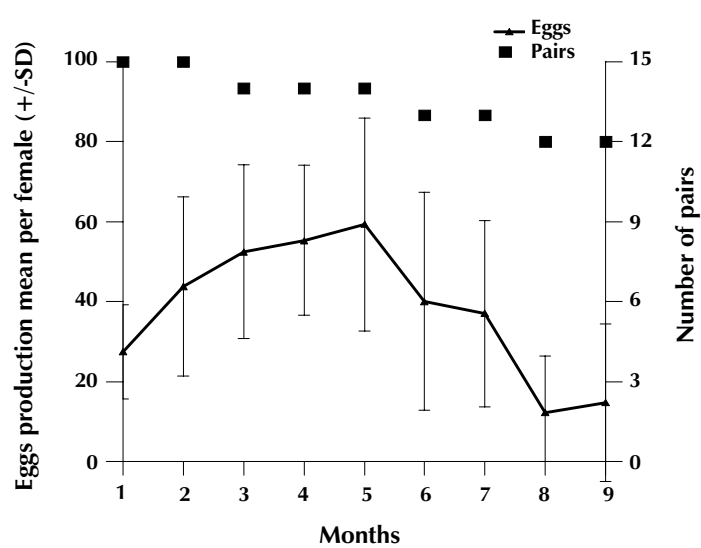

The mean number of eggs produced per female of Rhodnius domesticus during nine months of observation.

\section{TABLE III}

Partial stage specific life table for Rhodnius domesticus (Notation follows Southwood 1978)

\begin{tabular}{ccc}
\hline Stage & $l x$ & $d x$ \\
\hline Egg & 100 & 43 \\
I & 57 & 7 \\
II & 50 & 2 \\
III & 48 & 1 \\
IV & 47 & 0 \\
V & 47 & 1 \\
Adult & 46 & 46 \\
\hline
\end{tabular}

$R o=\frac{\begin{array}{c}\text { Number of females produced by cohort } \\ \mathrm{x} \text { mean eggs laid per female }\end{array}}{\text { Number of eggs beginning cohort }}=70.4$

$r=\log (R o) /$ Egg-to-egg generation time $=0.053$

$l x=$ number entering stage $x ; d x=$ number dying in stage $x$.

\section{DISCUSSION}

The development cycle of Triatominae varies according to species and environmental conditions, and is greatly influenced by the availability of appropriate blood sources (Schofield 1985). In this study, rearing conditions were optimised as far as possible, with an absence of competition between individuals during their development. Under these conditions, development was rapid in comparison with other species of Rhodnius. Lent and Valderrama (1977) for example, found a mean development time of 114 days for $R$. prolixus, 181.2 days for $R$. neivai, and 190.7 days for $R$. pictipes, when the insects were fed weekly on restrained mice and maintained at $25 \pm 1^{\circ} \mathrm{C}$ and $70-75 \%$ rh Under similar conditions, Jurberg and Rangel (1984) observed a mean development time of 358 days for $R$. pallescens. Soares et al. (1995) veri- 
fied a mean development time of 209.4 days for $R$. nasutus fed weekly on chickens, and Rocha et al. (1994) found a mean development time of 278 days for $R$. pictipes fed fortnightly on pigeons and maintained at $28^{\circ} \mathrm{C}$ and $80 \%$ rh.

Egg hatching rates in Rhodnius species also vary. They are generally above $80 \%$ (Szumlewicz 1975, Sherlock 1979) although lower average hatch rates of $53.3 \%$ and $64.9 \%$ have been recorded in established colonies of $R$. nasutus (Soares et al. 1995) and R. pictipes (Rocha et al. 1994) respectively. The $57 \%$ eclosion rate shown here may reflect the declining fertility of old females, since this variable was not controlled. This suspicion was confirmed in other experiments where we observed a hatch rate of over $80 \%$ in some egg batches from more recent colonies of $R$. domesticus (data not shown). Moreover, the rate of egg production in $R$. domesticus declines sharply from the fourth month after female emergence (Fig.) (cf. Guarneri et al. 1996).

Mortality declined during the nymphal development stage, following a similar pattern to that observed in $R$. nasutus (Soares et al. 1995) and $R$. pictipes (Rocha et al. 1994). In the youngest nymphs, mortality appeared to be mainly due to an incapacity to feed, since dead bugs were generally without significant intestinal contents. In contrast, mortality in the older nymphs occurred mainly during their moulting. On average, about $80 \%$ of each stage required only a single meal in order to moult to the next.

The short development time and high reproductive rate of $R$. domesticus recorded in this study probably represent close to the maximum achievable for this species under optimum conditions. The calculated rate of population increase $(R o=70.4$, $r=0.053$ ) is considerably higher than that calculated for $R$. prolixus under broadly similar laboratory conditions $(R o=49.3, r=0.024)$ (Rabinovich 1972, 1974), and mainly reflects the much shorter generation time of $R$. domesticus. It is known, however, that the maximum potential reproductive rates are rarely achieved in nature, and it can be dramatically reduced in sub-optimal conditions. Studies of $R$. domesticus on the Island of Santa Catarina showed that this species is invariably present at very low population densities, and is found only in habitats formed by epiphytic bromeliads in association with the nests of small mammals (Leal et al. 1961, Schlemper Jr et al. 1985). In the course of our studies, we have found it impossible to maintain $R$. domesticus by feeding them on chickens, so it may be that in nature the population density is restricted primarily by limited access to mammalian blood sources. There have been marked environmental changes on the Island of Santa Catarina over the last few decades, which may have reduced the availability of mammalian hosts and bromeliad habitats, thus contributing to the scarcity of $R$. domesticus in this region.

\section{REFERENCES}

D’Alessandro-Bacigalupo A, Saraiva NG 1992. Trypanosoma rangeli, p. 1-54. In JP Kreir, J Baker (eds), Parasitic Protozoa, Academic Press, London.

Galvão AB, Mello LR, Ferreira Neto J, Leal H 1961. Sobre a distribuição geográfica e infecção natural do Rhodnius domesticus Neiva \& Pinto, 1923. Rev Bras Mal Doenças Trop 13: 57-60.

Guarneri AA, Castilho CV, Eger I, Steindel M 1996. Biologia de Rhodnius domesticus Neiva \& Pinto, 1923 (Hemiptera, Reduviidae): ciclo evolutivo em condições controladas. 3a. Reunião Especial da SBPC, Florianópolis, SC, p. 566.

Leal H, Ferreira Neto JA, Martins CM 1961. Dados ecológicos sobre os triatomíneos silvestres na Ilha de Santa Catarina (Brasil). Rev Inst Med Trop São Paulo 3: 213-220.

Lent H, Valderrama A 1977. Observações em laboratório sobre o ciclo evolutivo de Rhodnius prolixus Stal, 1859, R. pictipes Stal, 1872 e R. neivai Lent, 1953. Rev Brasil Biol 37: 325-344.

Lent H, Wygodzinsky P 1979. Revision of the Triatominae (Hemiptera, Reduviidae), and their significance as vectors of Chagas' disease. Bull Am Nat Hist 163: 123-520.

Lent H, Jurberg J, Galvão C 1993. Rhodnius stali n.sp. afim de Rhodnius pictipes, 1872 (Hemiptera Reduviidae, Triatominae). Mem Inst Oswaldo Cruz 88: 605-614.

Jurberg G, Rangel EF 1984. Ciclo biológico de Rhodnius pallescens Barber, 1932 (Hemiptera Reduviidae, Triatominae) em laboratório. Mem Inst Oswaldo Cruz 79: 303-308.

Rabinovich JE 1972. Vital statistics of Triatominae (Hemiptera: Reduviidae) under laboratory conditions. II. Rhodnius prolixus Stal. Abstracts of the 14th International Congress of Entomology, Canberra, p. 291.

Rabinovich JE 1974. Demographic strategies in animal populations: a regression analysis, p. 19-40. In FB Golloy, E Medina (eds), Tropical Ecological Systems, Springer Verlag, New York.

Rocha DS, Galvão C, Jurberg J 1994. Biologia do Rhodnius pictipes Stal, 1872 em condições de laboratório (Hemiptera, Reduviidae, Triatominae). Mem Inst Oswaldo Cruz 89: 265-270.

Schlemper Jr BR, Steindel M, Gargioni R, Farias CJM, Oliveira R, Trianon JAX 1985. Reservatórios e vetores silvestres do Trypanosoma cruzi e suas relações com o domicílio humano na Ilha de Santa Catarina. Arq Cat Med 14: 91-96.

Schofield CJ 1985. Population dynamics and control of Triatoma infestans. Annales de la Socíeté Belge de Médecine Tropicale 65 (Suppl. 1): 149-164.

Schofield CJ 1994. Triatominae. Biología y Control, Eurocommunica Publications, 75 pp.

Sherlock IA 1979. Vetores, p. 42-88 In Z Brener, Z 
Andrade (eds), Trypanosoma cruzi e Doença de Chagas, Guanabara Koogan, Rio de Janeiro.

Soares MJS, Santos Filho PN, Bento DNC 1995. Estudo do ciclo evolutivo do Rhodnius nasutus Stal, 1859, em laboratório. Rev Soc Bras Med Trop 28: 113-116. Southwood TRE 1978. Ecological Methods, 2nd ed, Chapman \& Hall, London, 524 pp.

Steindel M, Carvalho Pinto JC, Toma HK, RibeiroRodrigues R, Romanha AJ 1991. Trypanosoma rangeli (Tejera, 1920) isolated from a sylvatic rodent (Echimys dasythrix) in Santa Catarina Island, Santa Catarina State: first report of this trypanosome in southern Brazil. Mem Inst Oswaldo Cruz 86: 7379.

Szumlewicz AP 1975. Laboratory colonies of triatomine, biology and population dynamics. In New Approaches in American Trypanosomiasis Research PAHO/WHO, Scientific Publication 318: 63-82. 